\title{
Concept Design, Development and Preliminary Physical and Chemical Characterization of Tamoxifen-Guided-Mesoporous Silica Nanoparticles
}

\author{
Candace M. Day ${ }^{1}$, Martin J. Sweetman ${ }^{1,2}{ }^{\oplus}$, Shane M. Hickey ${ }^{1}\left(\mathbb{D}\right.$, Yunmei Song ${ }^{1}$, Yongjun Liu ${ }^{3}$, Na Zhang ${ }^{3}$, \\ Sally E. Plush $1,2, *$ and Sanjay Garg $1,2, *$ (D)
}

1 Clinical and Health Sciences, University of South Australia, North Terrace, Adelaide, SA 5000, Australia; Candace.Day@mymail.unisa.edu.au (C.M.D.); Martin.Sweetman@unisa.edu.au (M.J.S.); Shane.Hickey@unisa.edu.au (S.M.H.); May.Song@unisa.edu.au (Y.S.)

2 Future Industry Institute, University of South Australia, Mawson Lakes, SA 5095, Australia

3 School of Pharmaceutical Science, Shandong University, Ji'nan 250012, China; Liuyongjun@sdu.edu.cn (Y.L.); Zhangnancy9@sdu.edu.cn (N.Z.)

* Correspondence: Sally.Plush@unisa.edu.au (S.E.P.); Sanjay.Garg@unisa.edu.au (S.G.)

Citation: Day, C.M.; Sweetman, M.J.; Hickey, S.M.; Song, Y.; Liu, Y.; Zhang, N.; Plush, S.E.; Garg, S. Concept Design, Development and Preliminary Physical and Chemical Characterization of Tamoxifen

-Guided-Mesoporous Silica

Nanoparticles. Molecules 2021, 26, 219. https://doi.org/10.3390/molecules26 010219

Academic Editors: Francesco Pellegrino, Federico Cesano, Marco Fabbiani and Chiara Negri

Received: 27 October 2020 Accepted: 16 December 2020 Published: 4 January 2021

Publisher's Note: MDPI stays neutral with regard to jurisdictional clai$\mathrm{ms}$ in published maps and institutional affiliations.

Copyright: (C) 2021 by the authors. Licensee MDPI, Basel, Switzerland. This article is an open access article distributed under the terms and conditions of the Creative Commons Attribution (CC BY) license (https:// creativecommons.org/licenses/by/ $4.0 /)$.
Abstract: Conventional chemotherapies used for breast cancer (BC) treatment are non-selective, attacking both healthy and cancerous cells. Therefore, new technologies that enhance drug efficacy and ameliorate the off-target toxic effects exhibited by currently used anticancer drugs are urgently needed. Here we report the design and synthesis of novel mesoporous silica nanoparticles (MSNs) equipped with the hormonal drug tamoxifen (TAM) to facilitate guidance towards estrogen receptors (ERs) which are upregulated in breast tumours. TAM is linked to the MSNs using a poly-L-histidine (PLH) polymer as a pH-sensitive gatekeeper, to ensure efficient delivery of encapsulated materials within the pores. XRD, HR-TEM, DLS, SEM, FT-IR and BET techniques were used to confirm the successful fabrication of MSNs. The MSNs have a high surface area ( $\left.>1000 \mathrm{~m}^{2} / \mathrm{g}\right)$; and a mean particle size of $150 \mathrm{~nm}$, which is an appropriate size to allow the penetration of premature blood vessels surrounding breast tumours. Successful surface functionalization was supported by FT-IR, XPS and TGA techniques, with a grafting ratio of approximately $29 \%$. The outcomes of this preliminary work could be used as practical building blocks towards future formulations.

Keywords: breast cancer; tamoxifen; targeting vector; poly-L-histidine; mesoporous silica nanoparticles; functionalized nanostructures; surface reactivity

\section{Introduction}

Breast cancer (BC) is one of the most fatal diseases among females worldwide, with approximately 350,000 new cases diagnosed in Europe, and 130,000 deaths reported annually [1]. In 2020, BC still remains the second leading cause of death from cancer in Australian women, with approximately 3000 deaths estimated [2]. Chemotherapeutic strategies to kill cancer cells by interfering with DNA and RNA synthesis are still the standard treatment options for solid tumours [3]. However, chemotherapies are limited by their non-specific mechanisms of action, whereby healthy cells are also affected during treatment [4]. Unlike invasive and non-selective chemotherapy, targeted therapy has emerged as a promising new treatment approach due to its ability to transport small therapeutic molecules and genetic cargoes to specific molecular targets located on tumour membranes, resulting in fewer unwanted toxic effects to healthy cells [5,6].

Various nanomaterials have been fabricated to carry anticancer drugs and deliver them specifically to tumours through the enhanced permeability and retention (EPR) effect, with higher accuracy than conventional chemotherapy, and fewer toxic side effects [7-9]. One of the most cutting-edge materials that has attracted substantial attention in the field of drug delivery are mesoporous silica nanoparticles (MSNs) [10-12]. These materials have 
pore diameters ranging from 2 to $50 \mathrm{~nm}$, very high porosity, good uniformity and large pore volumes, allowing them to host large quantities of both hydrophilic and lipophilic cargo, intended for therapeutic and diagnostic applications, whilst simultaneously protecting the cargo from systemic degradation and clearance [10-13]. Small-sized MCM-41-typed MSNs with hexagonal porous channels are the most commonly employed carriers for pharmaceutical applications, due to their small size, high stability, ease of synthesis and their ability to adsorb onto the surface of red blood cells without disturbing cell membrane or morphology $[14,15]$. By incorporating active therapeutics within the mesopores of MSNs, a smaller dose of drugs can be administered, but is selectively delivered to breast tumours via the EPR effect over a longer period of time, with reduced off-target toxicity [16]. Additionally, active targeted drug delivery can be achieved by functionalizing the surface of MSNs with different ligand molecules such as peptides, antibodies, aptamers and growth factors, so the drug-loaded-MSNs can recognize and selectively bind to receptors on the tumour surface [17-20].

Of all new BC cases diagnosed, $80 \%$ are in response to the overexpression of estrogen receptors (ERs); therefore, they are classified as estrogen receptor positive (ER+) BC [21-23]. ERs are promising targets for the active delivery of anticancer agents to solid breast tumours. The use of selective estrogen receptor modulators (SERMs) to block the effects of endogenous estrogen in breast tissues by competing with estrogen for ER binding has been established as one of the most effective strategies in BC therapy [24,25]. The treatment of BC with tamoxifen (TAM) has been the gold standard of hormonal therapy since 1973 and has been used as an affordable, life-saving tool for millions of women worldwide [26]. We recently reviewed how low concentrations of TAM can be employed as a targeting vector to direct the delivery of nanosystems containing other anticancer agents to solid tumours [26]. For example, Jain and colleagues incorporated TAM molecules into the lipid bilayers of liposomes, to guide the delivery of doxorubicin to ER+ tumours, which resulted in an improved uptake of liposomal doxorubicin by tumours, and subsequently higher rates of tumour cell death [27]. In another study, Dreaden et al. also used TAM as a targeting vector, to achieve selective and targeted delivery of plasmonic gold nanoparticles into ER+ BC cells [28]. The resulting system obtained a 2.7-fold enhanced drug potency when tested on MCF-7 cell lines. Even though the targetability of TAM on ER-upregulated BC and its safety profile has been well established [24-26], the research effort into utilizing its application for the delivery of other therapeutic and diagnostic agents in cancer therapy has not been properly explored. To the best of our knowledge, there has not been a study in which TAM is employed as a targeting vector to direct the delivery of MSN-based nano-drug delivery systems (DDSs).

Considerable research efforts have been made towards incorporating a controlled release capacity for drug-loaded DDSs. A variety of molecules can be used to block the MSN pores and act as gatekeepers to prevent the premature leakage of drug molecules from MSNs before they reach their site of action, achieving a release-on-demand mechanism [29-33]. The polypeptide poly(L-histidine) ( $\mathrm{PLH})$ is a $\mathrm{pH}$-sensitive gatekeeper ( $\mathrm{p} K_{\mathrm{a}}$ $\sim 6.10$ ) and offers several advantages compared to other $\mathrm{pH}$-sensitive options due to its biocompatibility and efficient degradation after use [34-37]. Under biological conditions ( $\mathrm{pH}$ 7.4), PLH molecules condense on the surface of MSNs, blocking the MSN pores and acting as gatekeepers to prevent the off-target release of the incorporated drugs [36]. Subsequently, as over time the PLH-gated nanosystems enter into the tumours via passive internalization, the PLH molecules will become protonated by the acidic tumour environment $(\mathrm{pH} \sim 5)$, resulting in the PLH molecules extending from the surface of the MSNs and opening the pores to release the drug payload [36,37].

Here we report the conceptual design, synthesis and preliminary physical and chemical characterization of a novel nanostructure that could serve as a platform for future DDSs. The uniqueness of our functional nanostructure is derived from the combination of successful synthesis methodology and targeting strategies from previous studies in the field of DDSs. This demonstrates a new theoretical concept for a triple-action DDS 
to be generated, which includes: (i) passive targeting using nanosized MSNs as carriers (MCM-41 species); (ii) active targeting by employing TAM as a targeting vector to selectively bind to ER-overexpressing breast tumours; and (iii) $\mathrm{pH}$-controlled drug release by grafting the polymer PLH onto the surface of MSNs to act as a pH-sensitive gatekeeper and prevent premature drug leakage. PLH and TAM are appended to the MSN in a stepwise manner, where the TAM is the peripheral moiety and is linked to the system via a non-toxic water-soluble spacer. This architecture prevents any potential $\pi-\pi$ interaction between the hydrophobic TAM and PLH from occurring. Our system offers an exciting and novel platform for the potential development of new nanobased DDSs that could provide enhanced accuracy and lower adverse toxic effects from loaded therapeutics and diagnostic agents (Scheme 1).

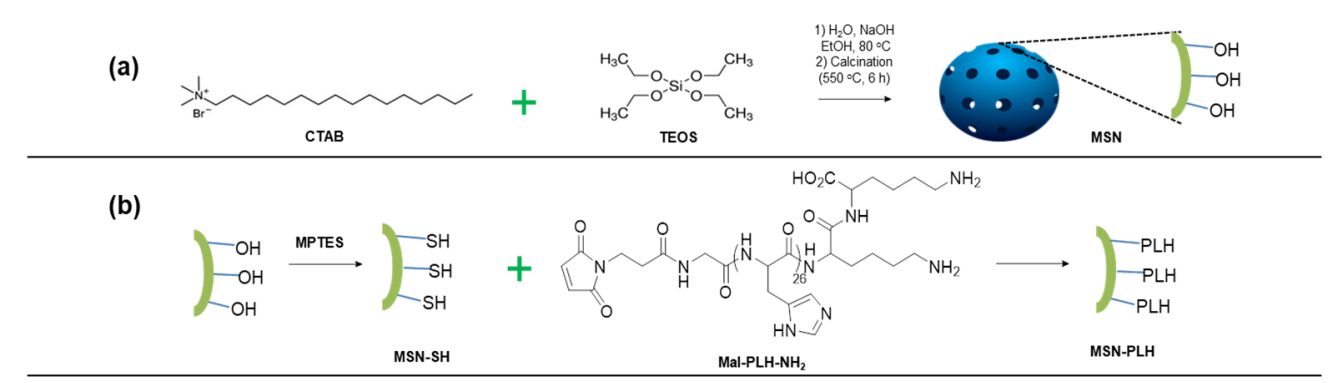

(c)

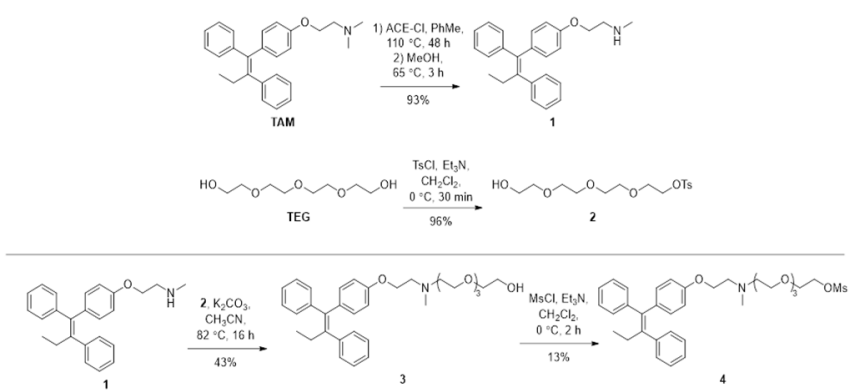

TAM-TEG-OMs

(d)

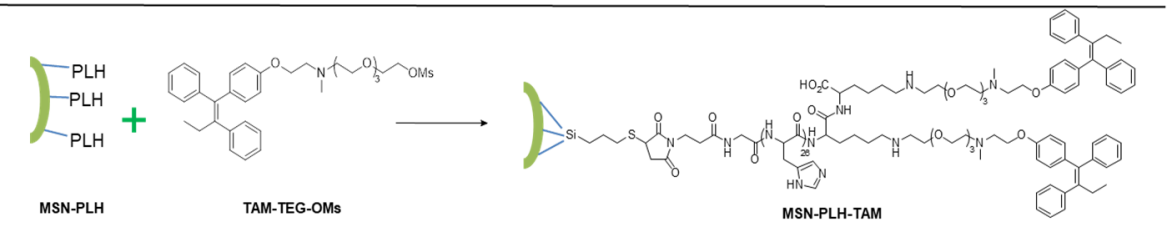

Scheme 1. Outline of the key steps to fabricate tamoxifen (TAM)-guided- poly(L-histidine) (PLH)-gated-MSN (MSNPLH-TAM): (a) Synthesis of native mesoporous silica nanoparticles (MSNs) via the Stöber method, using CTAB as the templating structure and TEOS as silica precursor. (b) The surface (OH-) moieties of MSNs were converted to thiols using MPTES, which were then conjugated to Mal-PLH-NH 2 molecules via a Michael addition at $\mathrm{pH}$, to give PLH-gated MSN (MSN-PLH). (c) Synthesis of TAM-TEG-OMs. (d) Conjugation between MSN-PLH and TAM-TEG-OMs to give the requisite MSN-PLH-TAM nanomaterial.

\section{Results and Discussion}

\subsection{Preparation of MSN System}

The first step in the preparation of our desired triple-action functionalized nanostructure was the synthesis of the native MSNs (Scheme 1a). Small-sized MCM-41-typed MSNs with hexagonal pores were fabricated using the sol-gel approach, with surfactant cetyltrimethylammonium bromide (CTAB) used as a templating structure and tetraethoxysilane (TEOS) as a silica precursor. In aqueous solution, CTAB will self-assemble into micellar structures. As the concentration of micelles in the reaction media increases, the resulting micelles will self-assemble into hexagonal architectures. Following the addition of TEOS, silica particles will simultaneously hydrolyze and condense on the templating structure surface $[10,11]$. It was observed during these experiments that the concentration of 
$\mathrm{NaOH}$ played a key role in the successful formation of MSNs. When low concentrations of $\mathrm{NaOH}$ were employed ( $0.2 \mathrm{M}$ to $1 \mathrm{M})$, MSNs did not form following the addition of TEOS. As the concentration of $\mathrm{NaOH}$ was increased to $2 \mathrm{M}$, MSNs were successfully formed in the solution following TEOS addition. This phenomenon can be explained by the efficient polymerization of alkoxide monomers during the hydrolysis and condensation steps following TEOS addition. The initial hydrolysis of TEOS esters generally takes place via an $S_{N} 2$ reaction between alkoxide groups and water molecules [38]. Following the micellar formation of templating CTAB molecules, it is possible that the reactive $(\mathrm{OH}-)$ ions replace some of the $(\mathrm{Br}-)$ ions from the $\mathrm{CTAB}$ and attach themselves onto the micellar surface [38]. This results in increased local concentrations of $(\mathrm{OH}-)$ ions around the CTAB molecules in the reaction, and micelles in the Stern region [38]. Eventually, this leads to a faster and more efficient hydrolysis, which dictates the successful formation of the silica network. In the final step, removal of the surfactant template was carried out by thermal treatment (calcination). A temperature of around $550{ }^{\circ} \mathrm{C}$ must be maintained for $6 \mathrm{~h}$; sufficient to remove the templating molecules but not harsh enough to disrupt the mesoporous structure.

The resulting MSNs displayed characteristic features of mesoporous materials, as shown by the $\mathrm{N}_{2}$ adsorption-desorption isotherm which demonstrated a typical type IV isotherm for mesoporous structures [39] (Figure 1a). The particles achieved a BrunauerEmmett-Teller surface area of over $1000 \mathrm{~m}^{2} / \mathrm{g}$ with pore diameter at $2.4 \mathrm{~nm}$ and pore volume averaged at $0.79 \mathrm{~cm}^{3} \mathrm{~g}^{-1}$ (Figure 1b). Additionally, highly ordered mesopores and the unique crystallized lattices of MCM- 41 were observed, as confirmed by the XRD measurement shown in Figure 1c. The XRD spectrum displays three distinct diffraction peaks, assigned as (100), (110) and (200) planes [36,40]. Furthermore, as demonstrated by FT-IR (Figure 1d), the MSNs display a hydroxyl $(-\mathrm{OH})$ signal [41], which is crucial for further surface grafting with PLH and TAM molecules.
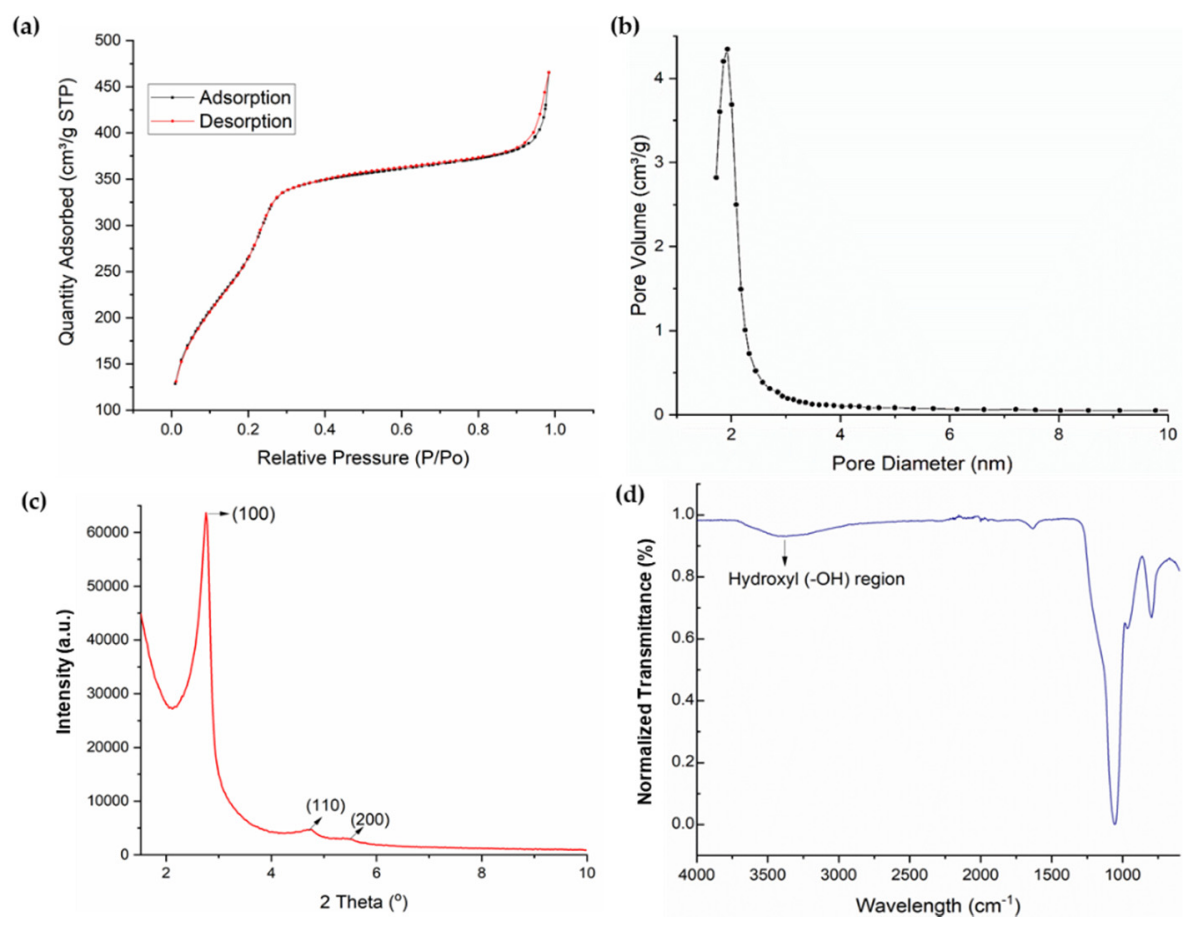

Figure 1. Physiochemical properties of native MSNs: (a) Type IV $\mathrm{N}_{2}$ adsorption-desorption isotherm of resulting particles, a distinct feature of mesoporous materials [39]. (b) Particles have an average pore diameter of $2.4 \mathrm{~nm}$, which fits the definition of MSNs having pore diameters ranging from 2 to $50 \mathrm{~nm}$ [11,12]. (c) MSNs demonstrated three distinct diffraction peaks, assigned as (100), (110) and (200) planes, a characteristic crystalized lattice of MCM-41 [36,40]. (d) FT-IR spectra of native MSNs demonstrating the $(-\mathrm{OH})$ signal [41] which is essential for further surface grafting. 
The fabricated MSNs were characterized to have a desirable nanosize for passive targeting, with a diameter of approximately $150 \mathrm{~nm}$ as determined by TEM and welldefined ordered long-range structure of inner mesopores (Figure 2a). MSNs were found to be uniform in morphology and size, with highly ordered porous channels, without the interconnection between each individual channel (Figure 2b). Dynamic light scattering (DLS) measurements suggested our MSNs were highly uniform and well dispersed; the hydrodynamic size of native MSNs was $232.97 \pm 9.56 \mathrm{~nm}$ with an ideal PDI of $0.31 \pm 0.063$.

(a)

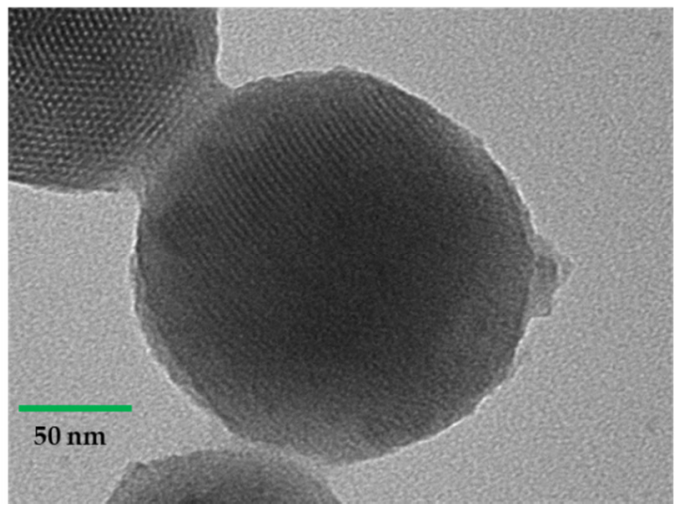

(b)

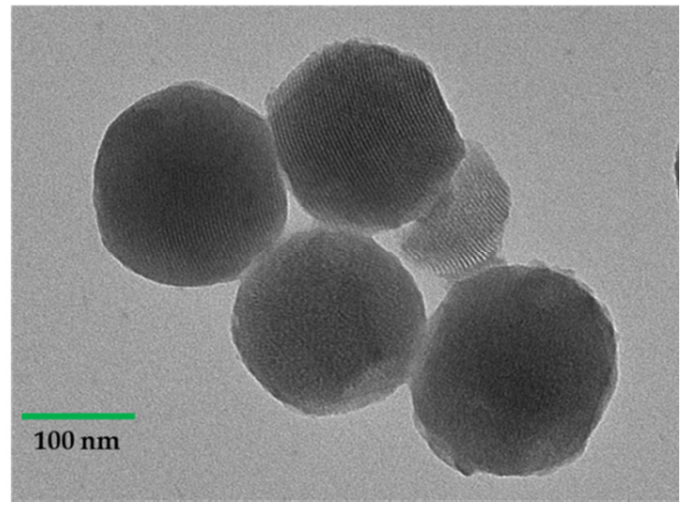

Figure 2. TEM images demonstrating the diameter and internal structure of MSNs: (a) MSNs images on the $50 \mathrm{~nm}$ scale-bar, demonstrating well-defined ordered long-range structure of inner mesopores. (b) MSNs on the $100 \mathrm{~nm}$ scale-bar, demonstrating highly ordered porous channels.

\subsection{Synthesis of MSN-PLH}

The next step in the preparation of our nanostructure was the attachment of the $\mathrm{pH}$-sensitive PLH molecules to the surface of the MSNs (Scheme 1b). To achieve this, MSNs were first modified with thiol groups on the surface using 3-mercaptopropyltriethoxysilane (MPTES). Due to the sequential surface modification procedure, a higher grafting of MPTES containing SH groups on the MSNs will result in a higher coverage of PLH. Previously, the synthesis of MSN-SH has been conducted in aqueous PBS buffer (pH 5) to achieve a convenient one-spot synthesis of the subsequent MSN-PLH in the same solvent system [36]. However, there are several examples within the literature which reported similar transformation being conducted in organic solvents including toluene (PhMe) [42]. With this in mind, two solvent systems were selected to assess the grafting efficiency of SH groups onto the MSN surface using MPTES: aqueous PBS buffer $(\mathrm{pH}=5)$ at $80^{\circ} \mathrm{C}$ and anhydrous PhMe at $110^{\circ} \mathrm{C}$. The introduction of SH onto the native MSN systems generated in PBS buffer and in anhydrous PhMe, namely MSN-SH (1) and MSN-SH (2) respectively, were characterized using FT-IR (Figure 3a). It was observed that MSN-SH (2) showed more intense aliphatic $\mathrm{CH}_{2}$ peaks in the $2800 \mathrm{~cm}^{-1}$ to $3150 \mathrm{~cm}^{-1}$ region [43] (Figure 3b), indicating a higher grafting amount of the MPTES and hence higher SH coverage on the surface of MSNs when PhMe was used as the solvent. In acidic aqueous solutions there is an enhanced possibility that the alkoxysilanes (of MPTES molecules) undergo hydrolysis and self-condensation [42]. This reaction between MPTES molecules leads to polysiloxane formation [42] and, consequently, a much lower surface grafting of thiol functionalities on native MSNs. Indeed, this is observed in the MSN-SH (1) sample. Furthermore, it has been reported that the self-oxidation of attached (SH-) groups (or the reaction between thiol groups of MPTES molecules with each other) is often reduced in organic solvents such as PhMe, as compared with aqueous solvents like PBS buffer [44]. Hence, more free thiol moieties are available in anhydrous PhMe for the reaction with native MSNs. The higher reaction temperature used with the PhMe solvent may also play a significant role in the grafting ratio. As more heat-induced energy was provided, silane groups were given more opportunities to react with the $(\mathrm{OH}-)$ groups on the surface of native MSNs. 
(a)

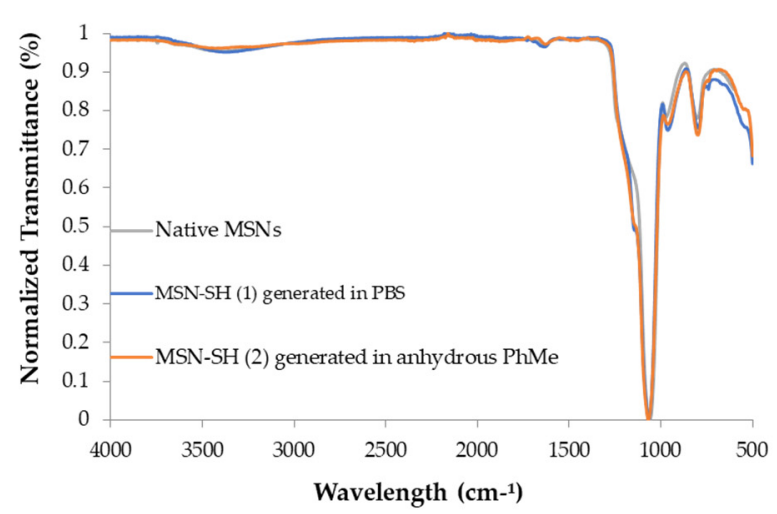

(b)

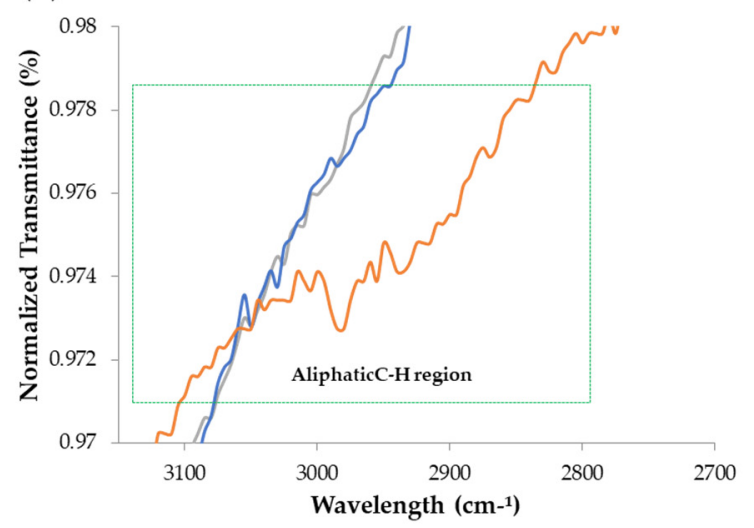

Figure 3. (a) FT-IR spectra of MSN-SH (1) synthesized in PBS pH 5 and MSN-SH (2) synthesized in anhydrous PhMe. (b) Enlarged region of spectrum $\left(2800 \mathrm{~cm}^{-1}\right.$ to $\left.3150 \mathrm{~cm}^{-1}\right)$ suggesting a greater presence of organic functionalities on the surface of MSN-SH (2), as compared to MSN-SH (1).

To prevent surface oxidation of the newly installed SH functionalities, MSN-SH (1) and MSN-SH (2) were immediately reacted with maleimide-functionalized PLH molecules to form MSN-PLH (1) and MSN-PLH (2), respectively. Installation of the PLH group to the MSN-SH nanoparticles was achieved using a Michael addition in PBS (pH 5). It is important that PBS buffer at an acidic $\mathrm{pH}$ was used for the reaction of MSN-SH molecules with Mal$\mathrm{PLH}-\mathrm{NH}_{2}$. At an acidic $\mathrm{pH}$, the maleimide groups are known to favour the reaction with sulfhydryl groups, resulting in stable thioether bonds [45]. In contrast, undesirable intra and inter-reactions between the maleimide groups and primary amines (from lysine groups) of Mal-PLH- $\mathrm{NH}_{2}$ molecules may occur at alkaline conditions, hindering the grafting of PLH onto the surface of MSNs [45].

The introduction of PLH onto the MSN-SH was firstly characterized using FT-IR (Figure 4). Compared to native MSNs, the FT-IR spectra of both batches of MSN-PLH compounds demonstrated new signals at $1665 \mathrm{~cm}^{-1}$, which is attributed to the secondary amide $\mathrm{C}=\mathrm{O}$ stretching vibration, and new signals at 1535 and $1445 \mathrm{~cm}^{-1}$ which indicate $\mathrm{N}-\mathrm{H}$ bending vibrations of the peptide bond in PLH [36], suggesting successful functionalization of both MSN-SH materials. As expected, due to the higher grafting of $\mathrm{SH}$ functionalities onto the MSN surface, MSN-PLH (2) appeared to have a higher grafting of PLH molecules on the surface compared to MSN-PLH (1), as indicated by the more profound peak intensities attributable to carbonyl and $\mathrm{N}-\mathrm{H}$ groups.

Thermogravimetric analysis (TGA) was then employed to determine the grafting ratio of PLH molecules onto the MSNs' surface. The data indicated a greater presence of organic molecules in the MSN-PLH (2) sample (grating ratio $=10.2 \%$ ) than in the MSNPLH (1) sample (grating ratio $=8.6 \%$ ) in accordance with the FT-IR (see Materials and Method for full experimental methodology). As such, MSN-PLH (2) was selected as the lead compound for further reactions.

\subsection{Synthesis of TAM-TEG-OMs}

Our nanostructure was developed in a modular fashion, where the targeting vector is attached to the linker as a separate entity before it is coupled to the MSN-PLH system. The aim of this design was that it would allow the targeting moiety to be altered easily in future applications. To prepare the TAM-TEG building block (Scheme 1c), the first step involved the demethylation of the commercially available TAM to form $\mathrm{N}$-Desmethyl tamoxifen (NDMT, 1). The synthesis of NDMT has been previously reported by Dreaden et al. [28] who heated a solution of TAM and 1-chloroethyl chloroformate ( $\mathrm{ACE}-\mathrm{Cl}$ ) in $\mathrm{CH}_{2} \mathrm{Cl}_{2}$ at reflux for $48 \mathrm{~h}$ in near equimolar amounts before $\mathrm{MeOH}$ was added, and then the reaction was stirred at reflux for a further $3 \mathrm{~h}$ to complete the conversion. However, in our hands no product formation was observed, even when the amount of 
$\mathrm{ACE}-\mathrm{Cl}$ was increased. When the reaction was conducted in a less volatile solvent (anhydrous PhMe), allowing the reaction temperature to be increased to $110{ }^{\circ} \mathrm{C}$, the presence of the desirable product (NDMT) was detected using ESI-MS analysis and starting material was consumed, ultimately allowing the isolation of NDMT 1 in $93 \%$.

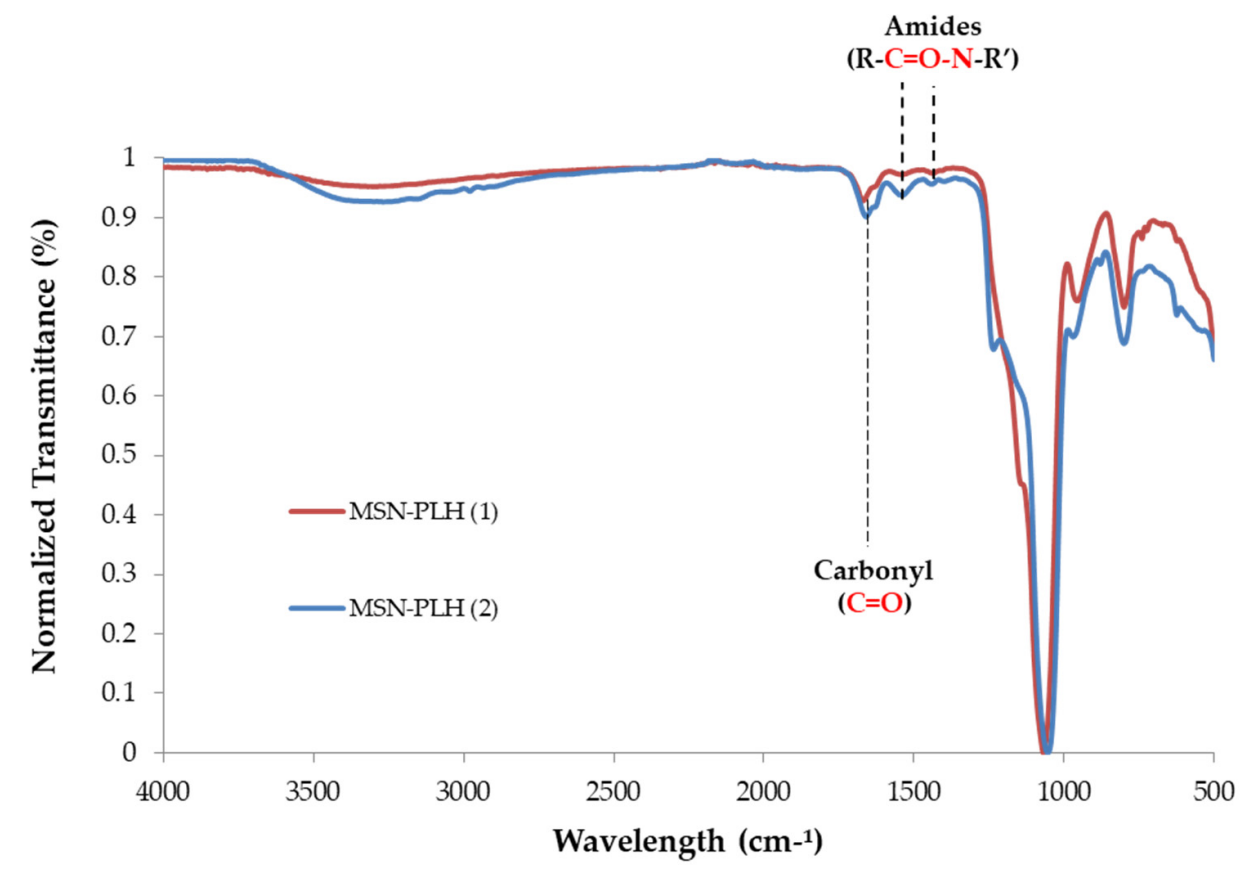

Figure 4. FT-IR spectra of MSN-PLH (1) and MSN-PLH (2).

The need for a water-soluble linking group led us to the TEG linker, often used due to its commercial availability and well-established chemistry. Another reason for selecting TEG was due to the concerns regarding the potential CNS depression associated with certain ethylene glycol (EG) species, arising from their metabolites such as glycolic acids (GA), diglycolic acid (DGA) and oxalates (OX) from EG and diethylene glycol (DEG) [46]. To the best of our knowledge no evidence of TEG forming GA, DGA or OX to any significant extent has been reported. Furthermore, unlike EG and DEG, the effects of TEG on the renal system are transient and minor [46]. To label NDMT with the linker TEG, the free amine of NDMT 1 was reacted with TEG-OTs 2, which was prepared in-house following previously reported procedures $[47,48]$, using basic conditions in $\mathrm{CH}_{3} \mathrm{CN}$ at reflux to give TAM-TEG conjugation 3. Finally, mesylation of the terminal alcohol group was achieved using methanesulfonyl chloride $(\mathrm{MsCl})$ to give the requisite TAM-TEG-OMs 4 building block for attachment to the MSN material (see Materials and Method for full reaction conditions). The final mesylation step was performed in a low yield (13\%), and both bromination and tosylation approaches of compound 3 were investigated; however, in each instance the desired TAM-conjugate was unable to be isolated in acceptable purity.

\subsection{Synthesis of MSN-PLH-TAM}

The final step in the formation of our novel functionalized nanostructure (Scheme 1d) is the coupling of TAM-TEG-OMs to the MSN-PLH (2) building block, where the OMs group behaves as a suitable leaving group for substitution by the PLH amino groups, to achieve the desired fully functionalized MSN-PLH-TAM (Figure 5). The reaction was carried out in $\mathrm{CH}_{3} \mathrm{CN}$ where sonication was required to initially aid in solubilisation, before stirring was continued at $80^{\circ} \mathrm{C}$ for $24 \mathrm{~h}$ (see Materials and Method for full reaction conditions). The characterization of MSN-PLH-TAM was firstly carried out by FT-IR analysis of MSN-PLH-TAM (Figure 6), which indicated successful conjugation of TAM-TEGOMs to MSN-PLH (2). This was demonstrated by the appearance of peaks at $1605 \mathrm{~cm}^{-1}$ and $1505 \mathrm{~cm}^{-1}$, representing the $C=C$ stretching of aromatic rings, and a signal at $705 \mathrm{~cm}^{-1}$ 
representing the $C=C$ bending [49]. Additionally, the signals attributed to amide $C=O$ groups at $1665 \mathrm{~cm}^{-1}$ were still present which confirmed that our final functionalized MSNs system still retained the previously grafted PLH molecules. The second characterization method employed to characterize MSN-PLH-TAM was TGA analysis. TGA was used to determine the grafting ratio of PLH and TEG onto MSNs, which further confirmed a ratio of $29 \%$ (increased from $10.2 \%$ as observed in MSN-PLH (2)), representing the presence of additional organic moieties (TAM-TEG conjugation) on the surface of the MSNs. Overall, these results obtained by FT-IR and TGA suggest that PLH and TAM were successfully grafted to the surfaces of the MSNs. As this final reaction is an $S_{N} 2$, the addition of a base was investigated. It was expected that the presence of $\mathrm{Et}_{3} \mathrm{~N}$ would enhance the reaction efficiency to produce higher grafting of TAM molecules on the surface of MSNPLH. Interestingly, the MSN-TAM-PLH synthesized in the presence of $\mathrm{Et}_{3} \mathrm{~N}$ only achieved a grafting ratio of approximately $26.8 \%$. The reduced grafting ratio may be as a result of competition between $\mathrm{Et}_{3} \mathrm{~N}$ and PLH (from MSN-PLH) for the binding to TAM-TEGOMs, reducing the final ratio of TAM onto PLH-MSNs. Therefore, the use of $\mathrm{Et}_{3} \mathrm{~N}$ was discontinued for future synthesis of MSN-PLH-TAM.

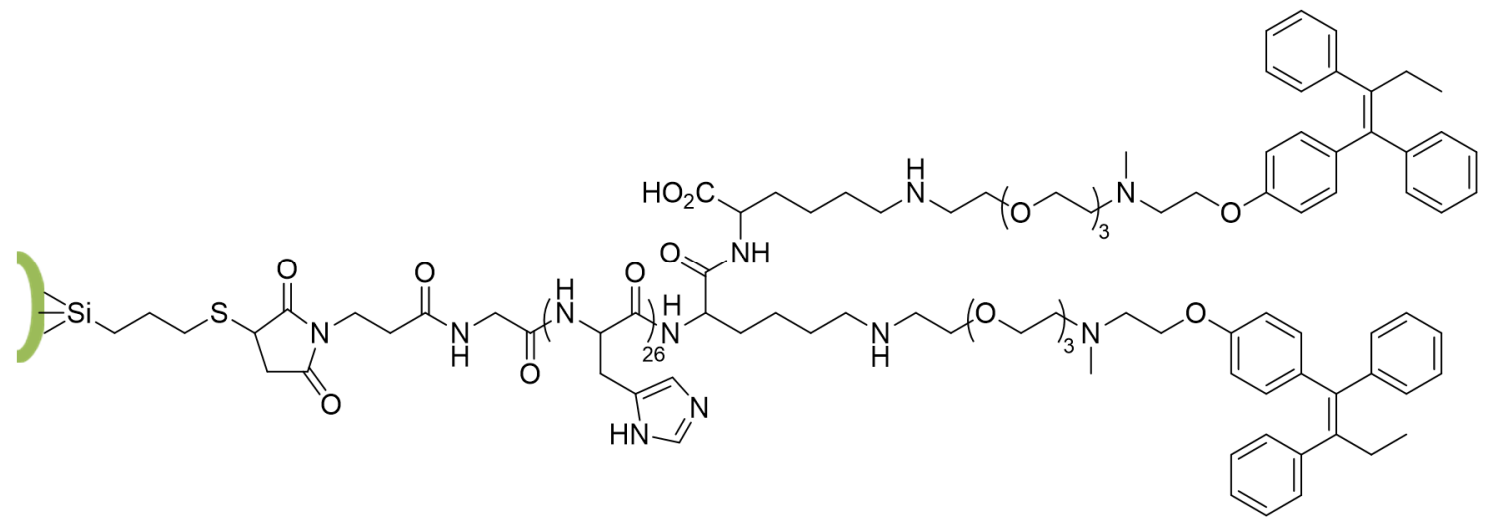

Figure 5. Structure of MSN-PLH-TAM.

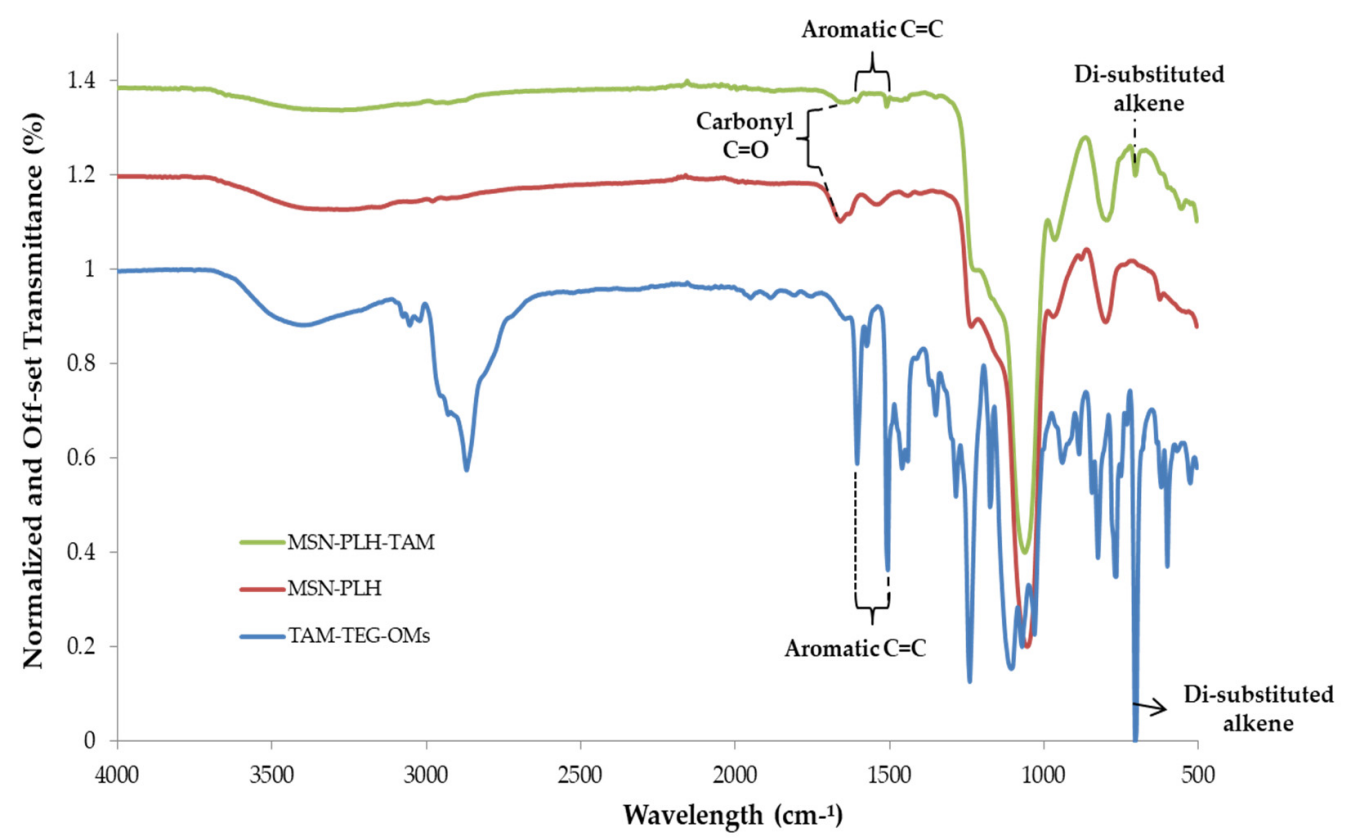

Figure 6. FT-IR spectra of MSN-PLH-TAM synthesized from the reaction between MSN-PLH (2) and TAM-TEG-OMs, via an $\mathrm{S}_{\mathrm{N}} 2$ mechanism with mesylates as leaving groups. MSN-PLH-TAM demonstrated characteristic peaks of PLH and TAM molecules, including secondary amide $\mathrm{C}=\mathrm{O}$, aromatic $\mathrm{C}=\mathrm{C}$ and di-substituted alkenes. 
In addition to FT-IR and TGA, survey X-ray photoelectron spectroscopy (XPS) was also employed to characterize surface elements and high-resolution XPS (HR-HXS) was employed to characterize the surface functional groups of fully functionalized MSNs. When comparing the survey spectra of MSN-PLH-TAM against unfunctionalized MSNs, a signal attributable to nitrogen was observed, which was not present in the native MSNs (Figure 7). The atomic percentage of each surface element on native MSNs and MSN-PLHTAM are reported in Table 1 below, including the absence of surface nitrogen on native MSNs and 2.2\% of surface nitrogen present in the MSN-PLH-TAM sample.

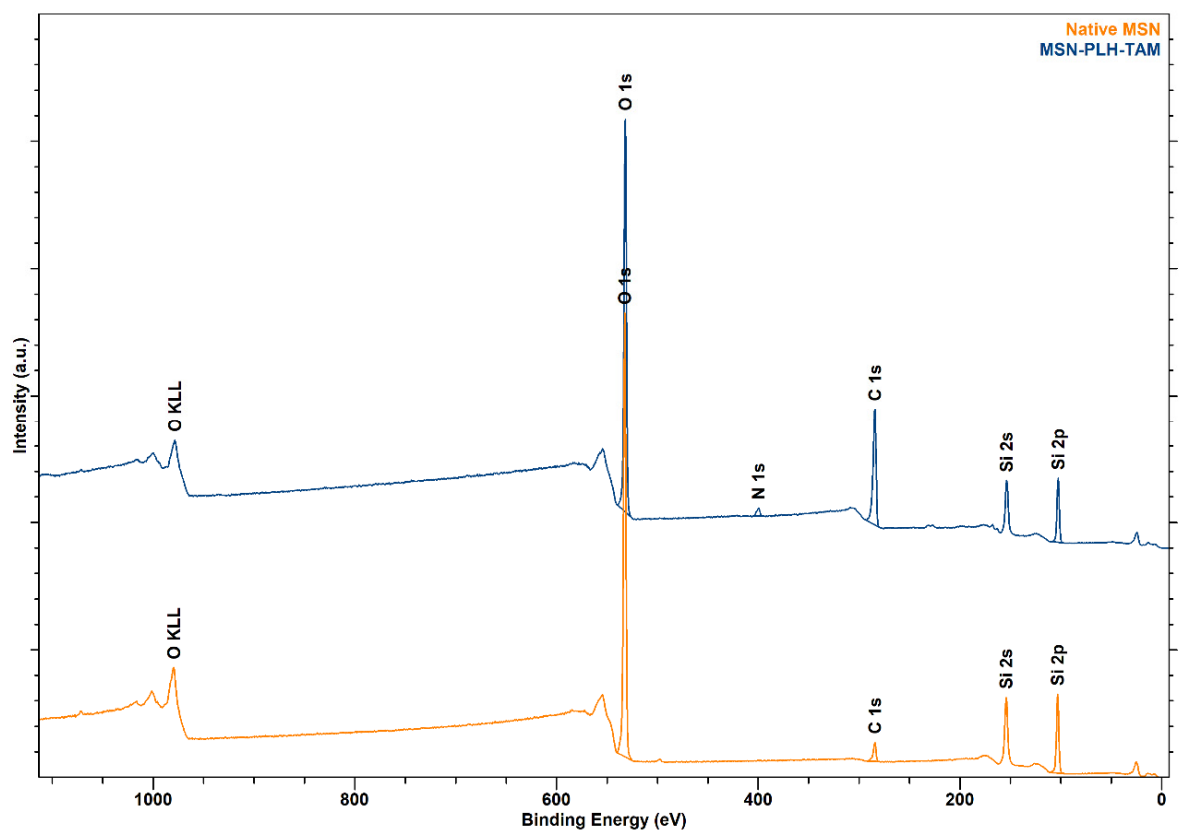

Figure 7. Survey XPS spectra of native MSN and MSN-PLH-TAM samples. The presence of nitrogen at $\approx 400 \mathrm{eV}$ was observed in MSN-PLH-TAM sample, but not in native MSNs.

Table 1. Survey XPS data of native MSNs vs. MSN-PLH-TAM.

\begin{tabular}{clc}
\hline Sample & SE & At\% \\
\hline Native MSNs & $\mathrm{O}$ & 66.12 \\
(unfunctionalized) & $\mathrm{C}$ & 8.44 \\
& $\mathrm{Si}$ & 25.44 \\
\hline & $\mathrm{O}$ & 38.83 \\
MSN-PLH-TAM & $\mathrm{C}$ & 44.77 \\
& $\mathrm{~N}$ & 2.20 \\
& $\mathrm{Si}$ & 14.20 \\
\hline
\end{tabular}

$\mathrm{SE}=$ Surface element. At $\%=$ Atomic percentage.

In addition to survey XPS, high-resolution XPS (HR-XPS) was also employed for the determination of functional groups on the surface of obtained MSN-PLH-TAM. The spectra of carbon (C) observed on the surface of MSN-PLH-TAM was successfully fitted into three components (Figure 8a) presenting characteristic functional groups of PLH and TAM, including $\mathrm{C}=\mathrm{O}$ at $288.5 \mathrm{eV}, \mathrm{C}-\mathrm{O}$ at $286 \mathrm{eV}$ and C-C at $284.8 \mathrm{eV}$ [50]. HR-XPS spectra of oxygen $(\mathrm{O})$ were also successfully fitted into three components (Figure $8 \mathrm{~b}$ ) representing the double bonding between carbon and oxygen, including organic $\mathrm{C}=\mathrm{O}$ at $532.8 \mathrm{eV}$ and organic $\mathrm{C}-\mathrm{O}$ at $\approx 533 \mathrm{eV}$ [51-53]. XPS results supported the FT-IR spectra and TGA reports for MSN-PLH-TAM, and confirmed the successful surface grafting of MSNs with both PLH and TAM. 

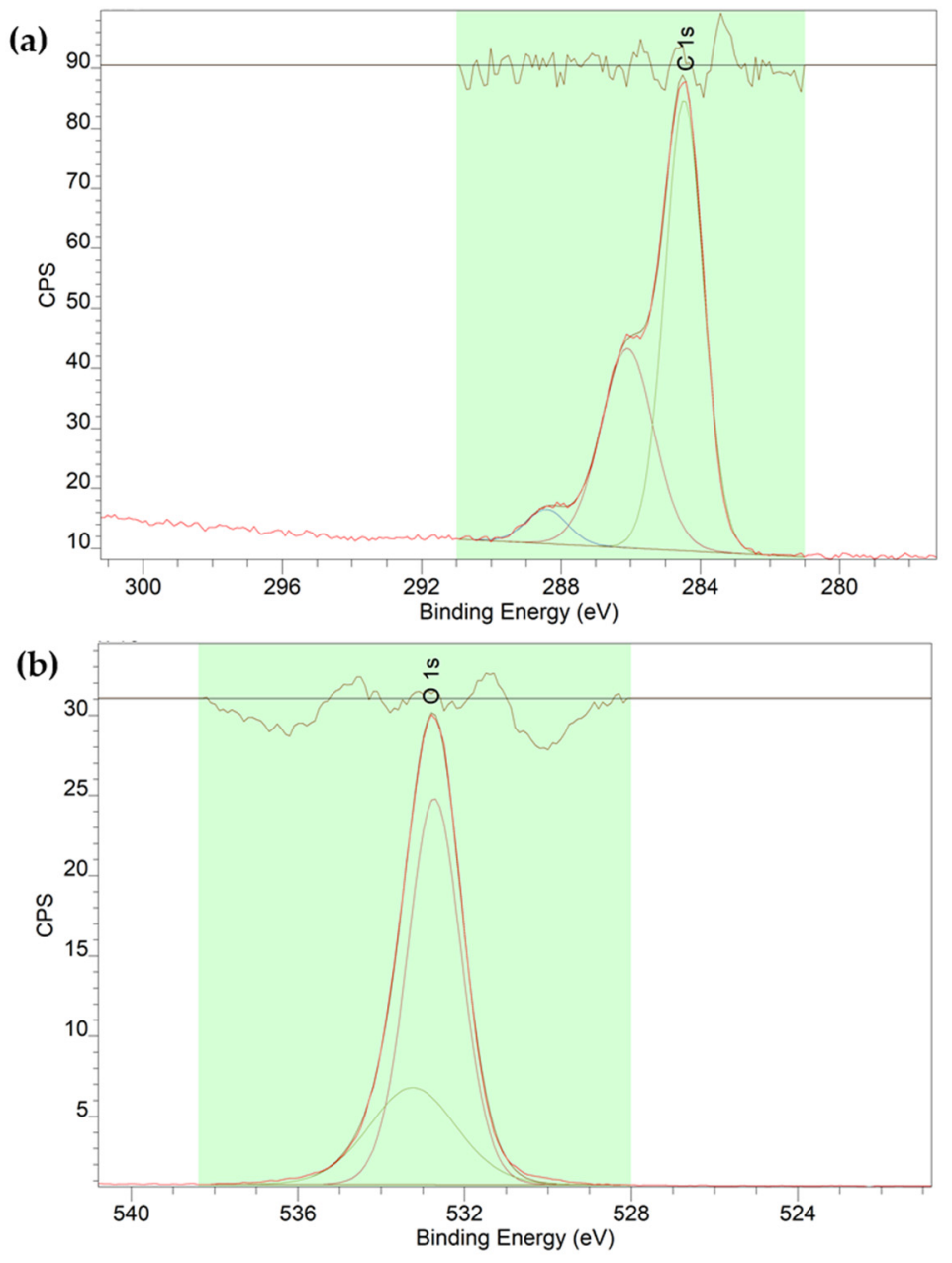

Figure 8. Deconvoluted HR-XPS spectra of the binding energies between carbon and oxygen are ascribed to (a) $\mathrm{C} 1 \mathrm{~s}$ and (b) $\mathrm{O} 1 \mathrm{~s}$. Key functional groups of PLH and TAM molecules on the surface of MSNs are observed, including organic $\mathrm{C}=\mathrm{O}$ and organic $\mathrm{C}-\mathrm{O}$.

\section{Materials and Methods}

\subsection{General Methods}

TAM was obtained from Combi-Blocks Inc (US). PLH (Mal-PLH-NH $/$ / Mal-GH26KK, purity $90 \%, 26$ units, $\mathrm{Mw}=4.05 \mathrm{kDa}$ ) was purchased from Leon Biological Technology Co. Ltd. (Nanjing, China). Anhydrous PhMe was obtained by drying over $3 \AA$ molecular sieves. All other reagents were purchased from Sigma Aldrich and used without further purification. Thin-layer chromatography was performed on silica gel $60 \mathrm{~F}_{254}$ plates purchased from Merch (Australia). All reactions performed at elevated temperatures were conducted using a heating mantle unless otherwise specified. All melting points were obtained using a digital ISG melting point apparatus and are uncorrected.

All ${ }^{1} \mathrm{H}$ spectra were collected on a Bruker AVANCE III $500 \mathrm{MHz}$ FT-NMR spectrometer. All NMR experiments were performed at $25^{\circ} \mathrm{C}$. Samples were dissolved in either $\mathrm{CDCl}_{3}$ or $\mathrm{CD}_{3} \mathrm{OD}$, with the residual solvent peak used as the internal reference- $\mathrm{CDCl}_{3} ; 7.26\left({ }^{1} \mathrm{H}\right)$; $\mathrm{CD}_{3} \mathrm{OD} ; 3.31\left({ }^{1} \mathrm{H}\right)$ and $49.0\left({ }^{13} \mathrm{C}\right)$ [54]. High resolution mass spectral data was collected using an AB Sciex TripleTOF 5600 mass spectrometer in a $5 \% \mathrm{H}_{2} \mathrm{O}$ in $\mathrm{MeOH}$ solvent system containing $0.1 \%$ formic acid. Analyte solutions were prepared in HPLC-grade $\mathrm{MeOH}$ (conc. $\approx 1 \mathrm{mg} \mathrm{mL}^{-1}$ ).

The mesostructures and the exact diameters of native MSNs were analysed by highresolution transmission electron microscopy (HR-TEM) (Hitachi S-4800, Tokyo, Japan) obtained on an HC electron microscope at an accelerating voltage of $100 \mathrm{kV}$. The hydrodymanic sizes of obtained particles were measured using DLS (Malvern Zetasizer Nano 
ZS, Worcestershire, UK). The DLS samples were prepared from a suspension of MSNs in $10^{-2} \mathrm{M} \mathrm{KCl}(0.1 \mathrm{~g} / \mathrm{L})$ and adjusted using a small quantity of $2 \mathrm{M} \mathrm{KOH}$ to neutral $\mathrm{pH}$ using a pH probe (Metrohm AG, Essen, Germany). Fourier transform infrared (FT-IR) PerkinElmer ATR (USA) was employed to determine the functional groups of obtained particles, with recorded spectral range from 400 to $4000 \mathrm{~cm}^{-1}$. To determine the crystalline structure of resulting particles, X-ray diffraction (XRD) (Malvern Panalytical Empyrean XRD, Malvern, UK) with a $\mathrm{Cu} \mathrm{K} \alpha$ radiation source $(\lambda=0.15406 \mathrm{~nm})$ was employed, operated at $40 \mathrm{kV}$ and $30 \mathrm{~mA}$. The surface area and pore volume were obtained from BrunauerEmmett-Teller (BET) ASAP 2420 (US). Survey and HR-XPS spectrum were obtained using Kratos Analytical (Shimazdu, Kyoto, Japan), and the peak fitting was conducted using the software CasaXPS (Casa Software Ltd., Teignmouth, UK).

\subsection{Synthesis of Native MSNs}

MCM-41 particles were synthesized following the Stöber (sol-gel) method adapted from $\mathrm{Mu}$ and colleagues [36]. A solution of CTAB (2.0 g, $5.49 \mathrm{~mol})$ in Milli-Q water (100 mL) and $2 \mathrm{M} \mathrm{NaOH}(720 \mu \mathrm{L})$ was heated to $80^{\circ} \mathrm{C}$ and stirred vigorously for approximately $30 \mathrm{~min}$ to allow micelles to form. TEOS $(1 \mathrm{~mL})$ was then added dropwise to the mixture, followed by $\mathrm{EtOH}(1 \mathrm{~mL})$ and the reaction was vigorously stirred at $80{ }^{\circ} \mathrm{C}$ for a further $2 \mathrm{~h}$. The resulting white precipitate was collected using centrifugation (8000 RPM, $20 \mathrm{~min}$, $\left.24^{\circ} \mathrm{C}\right)$, and washed with $\mathrm{H}_{2} \mathrm{O}(20 \mathrm{~mL} \times 3)$ and $\mathrm{EtOH}(20 \mathrm{~mL} \times 3)$, before drying in a desiccator for $24 \mathrm{~h}$. The resulting white particles were calcined at $550{ }^{\circ} \mathrm{C}$ for $6 \mathrm{~h}$, with a heating rate of $3^{\circ} \mathrm{C}$ per minute to remove the templating molecules.

\subsection{Synthesis of MSN-PLH}

The procedure was adapted and modified from $\mathrm{Mu}$ et al. [36]. Native MSNs (20 mg) were dispersed in anhydrous PhMe $(5 \mathrm{~mL})$ and ultrasonicated for $10 \mathrm{~min}$. The solution was then heated to $110{ }^{\circ} \mathrm{C}$, and MPTES $(25 \mu \mathrm{L})$ was added. The solution was stirred vigorously under an $\mathrm{N}_{2}$ atmosphere overnight. The reaction mixture was concentrated, and the white solid was washed extensively with anhydrous PhMe $(20 \mathrm{~mL})$ before being dissolved in PBS buffer solution ( $5 \mathrm{~mL}, \mathrm{pH}$ ). To the aqueous solution was added Mal-PLH-NH 2 (20 mg) and the reaction was stirred under an $\mathrm{N}_{2}$ atmosphere for $24 \mathrm{~h}$ at room temperature. The desired solid MSN-PLH was collected from the reaction mixture using centrifugation (8000 RPM, $\left.20 \mathrm{~min}, 24^{\circ} \mathrm{C}\right)$, washed with PBS buffer solution $(20 \mathrm{~mL} \times 3)$ and $\mathrm{H}_{2} \mathrm{O}(20 \mathrm{~mL}$ $\times 3)$ and then dried in a vacuum desiccator overnight.

\subsection{Synthesis of (Z)-2-(4-(1,2-Diphenylbut-1-en-1-yl)Phenoxy)-N-Methylethan-1-Amine $(\mathrm{NMDT}) 1$}

TAM (152 mg, $0.410 \mathrm{mmol})$ was dissolved in anhydrous PhMe $(6 \mathrm{~mL})$ at $0{ }^{\circ} \mathrm{C}$, followed by the addition of $\alpha$-chloroethyl chloroformate (ACE-Cl) $(200 \mu \mathrm{L}, 1.85 \mathrm{mmol})$. After $15 \mathrm{~min}$ at $0{ }^{\circ} \mathrm{C}$, the reaction was heated at reflux for $48 \mathrm{~h}$ under an $\mathrm{N}_{2}$ atmosphere. The reaction mixture was concentrated in vacuo to obtain a white waxy solid, to which $\mathrm{MeOH}(3 \mathrm{~mL})$ was added and the reaction was again heated at reflux for approximately $3 \mathrm{~h}$. The reaction mixture was concentrated in vacuo to give the title compound (138 $\mathrm{mg}, 93 \%)$ as a white solid. ${ }^{1} \mathrm{H}-\mathrm{NMR}\left(\mathrm{CD}_{3} \mathrm{OD}, 500 \mathrm{MHz}\right) \delta 7.20-7.10(10 \mathrm{H}, \mathrm{m}), 6.81(2 \mathrm{H}, \mathrm{d}, J=8.8 \mathrm{~Hz}), 6.65(2 \mathrm{H}$, $\mathrm{d}, J=8.8 \mathrm{~Hz}), 4.10(2 \mathrm{H}, \mathrm{t}, J=5.2 \mathrm{~Hz}), 3.33(2 \mathrm{H}, \mathrm{t}, J=5.2 \mathrm{~Hz}), 2.71(3 \mathrm{H}, \mathrm{s}), 2.44(2 \mathrm{H}, \mathrm{q}$, $J=7.5 \mathrm{~Hz}), 0.89(3 \mathrm{H}, \mathrm{t}, J=7.6 \mathrm{~Hz})$. HRMS (ESI-TOF) $m / z:[\mathrm{M}+\mathrm{H}]$ calcd for $\mathrm{C}_{25} \mathrm{H}_{28} \mathrm{NO}$ 358.2171; found, 358.2182. Data (Figure S1 in Supplementary Materials) is in accordance with literature [28].

\subsection{Synthesis of 2-(2-(2-(2-Hydroxyethoxy)Ethoxy)Ethoxy)Ethyl 4-Methylbenzenesulfonate 2}

A solution of TEG $(10.19 \mathrm{~g}, 52.4 \mathrm{mmol})$ in anhydrous $\mathrm{CH}_{2} \mathrm{Cl}_{2}(10 \mathrm{~mL})$ under an $\mathrm{N}_{2}$ atmosphere was stirred at $0{ }^{\circ} \mathrm{C}$ for $30 \mathrm{~min}$ before $\mathrm{TsCl}(1.10 \mathrm{~g}, 5.24 \mathrm{mmol})$ and $\mathrm{Et}_{3} \mathrm{~N}(1.1 \mathrm{~mL}$, $7.89 \mathrm{mmol}$ ) were added sequentially. The mixture was stirred overnight before the reaction mixture was diluted in $\mathrm{CH}_{2} \mathrm{Cl}_{2}(10 \mathrm{~mL})$ and transferred to a separatory funnel. The organic portion was washed with $\mathrm{H}_{2} \mathrm{O}(3 \times 10 \mathrm{~mL})$, dried $\left(\mathrm{Na}_{2} \mathrm{SO}_{4}\right)$, filtered and concentrated 
in vacuo to give the title compound as a colourless oil $(1.750 \mathrm{~g}, 96 \%) .{ }^{1} \mathrm{H} \mathrm{NMR}\left(\mathrm{CDCl}_{3}\right.$, $500 \mathrm{MHz}) \delta 7.78(2 \mathrm{H}, \mathrm{d}, J=8.4 \mathrm{~Hz}), 7.33(2 \mathrm{H}, \mathrm{d}, J=8.4 \mathrm{~Hz}), 4.14(2 \mathrm{H}, \mathrm{t}, J=4.8 \mathrm{~Hz})$, 3.59-3.70 $(14 \mathrm{H}, \mathrm{m}), 2.43(3 \mathrm{H}, \mathrm{s})$. HRMS (ESI-TOF) $m / z$ : $[\mathrm{M}+\mathrm{H}]$ calcd for $\mathrm{C}_{15} \mathrm{H}_{25} \mathrm{O}_{7} \mathrm{~S}$ 349.1316; found 349.1312. Data (Figure S2 in Supplementary Materials) is in accordance with literature [47].

3.6. Synthesis of (Z)-1-(4-(1,2-Diphenylbut-1-en-1-yl)Phenoxy)-3-Methyl-6,9,12-Trioxa-3Azatetradecan-14-ol 3

The procedure was adapted and modified from two previously published methods $[47,48]$. A mixture of 1 (113. $68 \mathrm{mg}, 0.318 \mathrm{mmol}), 2$ (132.6 mg, $0.381 \mathrm{mmol}), \mathrm{K}_{2} \mathrm{CO}_{3}(175.5 \mathrm{mg}$, $1.272 \mathrm{mmol})$ and $\mathrm{CH}_{3} \mathrm{CN}(4.5 \mathrm{~mL})$ was stirred at reflux overnight. The reaction mixture was concentrated in vacuo to obtain a yellow oil which was diluted in $\mathrm{CH}_{2} \mathrm{Cl}_{2}(10 \mathrm{~mL})$ and transferred to a separatory funnel. The organic portion was washed with $\mathrm{H}_{2} \mathrm{O}(3 \times 10 \mathrm{~mL})$, dried $\left(\mathrm{Na}_{2} \mathrm{SO}_{4}\right)$, filtered and concentrated in vacuo to give a dark yellow oil. The crude material was purified using column chromatography (MeOH: $\mathrm{CH}_{2} \mathrm{Cl}_{2} 5: 25 \mathrm{v} / \mathrm{v}$ ) to give the title compound as a yellow oil $(74 \mathrm{mg}, 43 \%) . R_{f}=0.36\left(\mathrm{MeOH}: \mathrm{CH}_{2} \mathrm{Cl}_{2} 5: 25 \mathrm{v} / \mathrm{v}\right)$. ${ }^{1} \mathrm{H}$ NMR ( $\left.\mathrm{CDCl}_{3}, 500 \mathrm{MHz}\right): 7.23-7.10(10 \mathrm{H}, \mathrm{m}), 6.75(2 \mathrm{H}, \mathrm{d}, J=8.8 \mathrm{~Hz}), 6.53(2 \mathrm{H}, \mathrm{d}$, $J=8.8 \mathrm{~Hz}), 3.96(2 \mathrm{H}, \mathrm{t}, J=5.8 \mathrm{~Hz}), 3.67(2 \mathrm{H}, \mathrm{t}, J=4.3 \mathrm{~Hz}), 3.67-3.62(12 \mathrm{H}, \mathrm{m}), 2.87(2 \mathrm{H}$, $\mathrm{t}, J=5.5 \mathrm{~Hz}), 2.75(2 \mathrm{H}, \mathrm{t}, J=5.5 \mathrm{~Hz}), 2.49(2 \mathrm{H}, \mathrm{q}, J=7.6 \mathrm{~Hz}), 2.37(3 \mathrm{H}, \mathrm{s}), 0.91(3 \mathrm{H}, \mathrm{t}$, $J=7.6 \mathrm{~Hz}$ ). HRMS (ESI-TOF) $m / z:\left[\mathrm{M}+\mathrm{H}\right.$ ] calcd for $\mathrm{C}_{33} \mathrm{H}_{44} \mathrm{NO}_{5} 534.3219$, found 534.3214 . Data (Figure S3 in Supplementary Materials) is in accordance with literature $[47,48]$.

3.7. Synthesis of (Z)-1-(4-(1,2-Diphenylbut-1-en-1-yl)Phenoxy)-3-Methyl-6,9,12-Trioxa-3Azatetradecan-14-yl Methanesulfonate 4

The procedure was adapted from a previous study on the mesylation of alcohols [55]. $\mathrm{MeSO}_{2} \mathrm{Cl}(23 \mu \mathrm{L}, 0.287 \mathrm{mmol})$ was added dropwise into a solution of compound $3(102 \mathrm{mg}$, $0.191 \mathrm{mmol}), \mathrm{Et}_{3} \mathrm{~N}(80 \mu \mathrm{L}, 0.578 \mathrm{mmol})$ and anhydrous $\mathrm{CH}_{2} \mathrm{Cl}_{2}(5 \mathrm{~mL})$ at $0{ }^{\circ} \mathrm{C}$. The solution was stirred under an $\mathrm{N}_{2}$ atmosphere for $2 \mathrm{~h}$. The reaction mixture was transferred to a separatory funnel and washed with $\mathrm{H}_{2} \mathrm{O}(3 \times 10 \mathrm{~mL})$. The organic portion was dried $\left(\mathrm{Na}_{2} \mathrm{SO}_{4}\right)$, filtered and concentrated in vacuo to give a yellow oil. The crude material was purified using column chromatography $\left(1-10 \% \mathrm{MeOH}\right.$ in $\left.\mathrm{CH}_{2} \mathrm{Cl}_{2}\right)$ to give the desired product as a colourless oil $(45 \mathrm{mg}, 13 \%) . R_{f}=0.57\left(10 \% \mathrm{MeOH}\right.$ in $\left.\mathrm{CH}_{2} \mathrm{Cl}_{2}\right) .{ }^{1} \mathrm{H} \mathrm{NMR}$ $\left(\mathrm{CD}_{3} \mathrm{OD}, 500 \mathrm{MHz}\right.$; Figure S4 in Supplementary Materials) $87.21-7.11(10 \mathrm{H}, \mathrm{m}), 6.77(2 \mathrm{H}$, $\mathrm{d}, J=8.9 \mathrm{~Hz}), 6.58(2 \mathrm{H}, \mathrm{d}, J=8.9 \mathrm{~Hz}), 4.32(2 \mathrm{H}, \mathrm{t}, J=4.4 \mathrm{~Hz}), 3.99(2 \mathrm{H}, \mathrm{t}, J=5.6 \mathrm{~Hz})$, $3.71(2 \mathrm{H}, \mathrm{t}, J=4.4 \mathrm{~Hz}), 3.61-3.71(10 \mathrm{H}, \mathrm{m}), 3.07(3 \mathrm{H}, \mathrm{s}), 2.86(2 \mathrm{H}, \mathrm{t}, J=5.9 \mathrm{~Hz}), 2.73(2 \mathrm{H}$, $\mathrm{t}, J=5.9 \mathrm{~Hz}), 2.45(2 \mathrm{H}, \mathrm{q}, J=7.5 \mathrm{~Hz}), 2.38(3 \mathrm{H}, \mathrm{s}), 0.90(3 \mathrm{H}, \mathrm{t}, J=7.4 \mathrm{~Hz}) .{ }^{13} \mathrm{C}\{1 \mathrm{H}\} \mathrm{NMR}$ $\left(\mathrm{CD}_{3} \mathrm{OD}, 125 \mathrm{MHz}\right.$; Figure S5 in Supplementary Materials) $\delta$ 158.2, 145.1, 143.8, 142.7, 139.9, 137.0, 133.0, 130.9, 130.4, 129.2, 129.0, 127.7, 127.2, 114.5, 71.6, 71.54, 71.51, 71.4, 70.9, 69.6, $66.4,57.8,57.3,43.6,37.5,29.9,13.8$. HRMS (ESI-TOF) $m / z:\left[\mathrm{M}+\mathrm{H}\right.$ ] calcd for $\mathrm{C}_{34} \mathrm{H}_{46} \mathrm{NO}_{7} \mathrm{~S}$ 612.2950 , found 612.2948 . Resulting compound achieved $>97 \%$ purity (Figure S6 and Table S1 in Supplementary Materials).

\subsection{Synthesis of MSN-PLH-TAM}

PLH-grafted MSNs (33 mg) were ultrasonically dispersed in anhydrous $\mathrm{CH}_{3} \mathrm{CN}(1 \mathrm{~mL})$ before a solution of TAM-TEG-OMs $4(33 \mathrm{mg}, 0.054 \mathrm{mmol})$ in $\mathrm{CH}_{3} \mathrm{CN}(3 \mathrm{~mL})$ was added. The suspension was stirred at $80^{\circ} \mathrm{C}$ for $24 \mathrm{~h}$. The resulting white precipitate was collected using centrifugation (8000 RPM, $15 \mathrm{~min}$ ) and washed extensively with $\mathrm{CH}_{3} \mathrm{CN}(20 \mathrm{~mL} \times 3)$, $\mathrm{H}_{2} \mathrm{O}(20 \mathrm{~mL} \times 3)$, and left to dry under vacuum in a desiccator overnight to give $20 \mathrm{mg}$ of white solid. The combined graft ratio of total organic functionalities (including TAM and PLH) onto MSN surface was determined by TGA (Discovery TGA 550). Approximately $6 \mathrm{mg}$ samples were heated at a rate of $10^{\circ} \mathrm{C} / \mathrm{min}$ under a flow of nitrogen, from room temperature to $800^{\circ} \mathrm{C}$. The grafting ratio of surface organic functionalities was determined using the equation below:

$$
\frac{L 1}{100 \%-L 1}=\frac{L 2-W}{100 \%-L 2}
$$


where $L_{1}$ is the weight loss of native MSNs upon heating to $800{ }^{\circ} \mathrm{C}, L_{2}$ is the weight loss of fully functionalized MSNs and $W$ is the graft ratio $[36,56]$.

\section{Conclusions}

We have successfully synthesized a novel and versatile MSN-based nanostructure, functionalized with the FDA-approved hormonal drug tamoxifen that acts as a guiding vector. The challenging, multistep procedure to synthesize this system required thorough optimization to achieve appropriate grafting densities of both the PLH and TAM. Each step of the synthesis has been extensively characterized to demonstrate the successful fabrication of this novel system. In terms of future applications, our nanostructure can serve as a nanocarrier system for incorporated therapeutic and diagnostic molecules for cancer treatment, given the well-establish property of MSN-based materials to host both hydrophobic and hydrophilic cargoes [26]. For example, a new generation of DDSs derived from our study could combine the advantageous structural properties of MSNs and the safety, targeting ability and efficacy of TAM together with the biocompatibility and high biodegradability of the $\mathrm{pH}$-sensitive material $\mathrm{PLH}$, for potentially enhanced BC treatment outcomes. It is expected that the triple-action system that we have developed holds remarkable promise as a drug delivery vector for cancer therapy. Our future work will investigate the release kinetics and breast cancer targeting capacity, following the encapsulation of our nanostructure with therapeutic and imaging agents used in the treatment and diagnosis of breast cancer.

Supplementary Materials: Figures S1-S4: ${ }^{1} \mathrm{H}$ NMR spectra of 1-4; Figure S5: ${ }^{13} \mathrm{C}$ NMR spectrum of compound 4; Figure S6: RP-HPLC chromatogram for 4; Table S1: RP-HPLC peaks and integrations for 4 .

Author Contributions: Conceptualization, C.M.D.; methodology, C.M.D., S.E.P., M.J.S., S.M.H., S.G., Y.L. and N.Z.; software, C.M.D. and Y.L. (TEM); validation, C.M.D.; formal analysis, C.M.D.; investigation, C.M.D.; resources, S.G., S.E.P. and Y.S.; data curation, C.M.D.; writing—original draft preparation, C.M.D.; writing—review and editing, S.E.P., M.J.S., S.M.H., Y.L., N.Z. and S.G.; visualization, C.M.D., M.J.S. and S.E.P.; supervision, S.E.P., S.G., N.Z. and Y.S.; project administration, S.G. and Y.S.; funding acquisition, Y.S., S.E.P. and Y.L. All authors have read and agreed to the published version of the manuscript.

Funding: This research did not receive any specific grant from funding agencies in the public, commercial or not-for-profit sectors.

Acknowledgments: The authors would like to acknowledge John Denman and Rajesh Baskaran (Mawson Lakes, UniSA) for their thorough training with TGA, BET and XRD. Authors would like to acknowledge Mohammad Arafat and Samuel Nitschke for their support in the project.

Conflicts of Interest: The authors declare no conflict of interest.

Sample Availability: Approximately $50 \mathrm{mg}$ of the native MSNs (Scheme 1a) and MSN-PLH (Scheme 1b) are available from the authors. Compounds 1-4 (Scheme 1c) and MSN-PLH-TAM (Scheme 1d) are only synthesized on demand.

\section{References}

1. Tyczynski, J.; Plesko, I.; Aareleid, T.; Primic-Zakelj, M.; Dalmas, M.; Kurtinaitis, J.; Stengrevics, A.; Parkin, D.M. Breast cancer mortality patterns and time trends in 10 new EU member states: Mortality declining in young women, but still increasing in the elderly. Int. J. Cancer 2004, 112, 1056-1064. [CrossRef] [PubMed]

2. Breast Cancer in Australia Statistics. Available online: www.canceraustralia.gov.au/affected-cancer/cancer-types/breast-cancer/ statistics (accessed on 1 October 2020).

3. Sugerman, D.T. Chemotherapy. JAMA 2013, 310, 218. [CrossRef] [PubMed]

4. Tierney, A.J.; Leonard, R.C.; Taylor, J.; Closs, S.J.; Chetty, U.; Rodger, A. Side effects expected and experienced by women receiving chemotherapy for breast cancer. BMJ 1991, 302, 272. [CrossRef]

5. Breast cancer targeted therapy: Successes and challenges. Lancet 2017, 389, 2350. [CrossRef]

6. Higgins, M.J.; Baselga, J. Targeted therapies for breast cancer. J. Clin. Investig. 2011, 121, 3797-3803. [CrossRef]

7. Ventola, C.L. Progress in nanomedicine: Approved and investigational nanodrugs. Phram. Ther. 2017, 42, 742-755. 
8. Sharma, A.; Jain, N.; Sareen, R. Nanocarriers for Diagnosis and Targeting of Breast Cancer. BioMed Res. Int. 2013, $2013,960821$. [CrossRef]

9. Dai, Y.; Xu, C.; Sun, X.; Chen, X. Nanoparticle design strategies for enhanced anticancer therapy by exploiting the tumour microenvironment. Chem. Soc. Rev. 2017, 46, 3830-3852. [CrossRef]

10. Narayan, R.; Nayak, U.Y.; Raichur, A.M.; Garg, S. Mesoporous Silica Nanoparticles: A Comprehensive Review on Synthesis and Recent Advances. Pharmaceutics 2018, 10, 118. [CrossRef]

11. Chircov, C.; Spoială, A.; Păun, C.; Crăciun, L.; Ficai, D.; Ficai, A.; Andronescu, E.; Turculeț, S.C. Mesoporous Silica Platforms with Potential Applications in Release and Adsorption of Active Agents. Molecules 2020, 25, 3814. [CrossRef]

12. Rosenholm, J.M.; Mamaeva, V.; Sahlgren, C.; Lindén, M. Nanoparticles in targeted cancer therapy: Mesoporous silica nanoparticles entering preclinical development stage. Nanomedicine 2012, 7, 111-120. [CrossRef] [PubMed]

13. Loryuenyong, V.; Muanghom, T.; Apinyanukul, T.; Rutthongjan, P. Synthesis of templated mesoporous silica nanoparticles under base catalysis. Adv. Appl. Ceram. 2011, 110, 335-339. [CrossRef]

14. Zhao, Y.; Sun, X.; Zhang, G.; Trewyn, B.G.; Slowing, I.I.; Lin, V.S.-Y. Interaction of Mesoporous Silica Nanoparticles with Human Red Blood Cell Membranes: Size and Surface Effects. ACS Nano 2011, 5, 1366-1375. [CrossRef] [PubMed]

15. Slowing, I.I.; Wu, C.-W.; Vivero-Escoto, J.L.; Lin, V.S.-Y. Mesoporous Silica Nanoparticles for Reducing Hemolytic Activity towards Mammalian Red Blood Cells. Small 2009, 5, 57-62. [CrossRef] [PubMed]

16. Watermann, A.; Brieger, J. Mesoporous Silica Nanoparticles as Drug Delivery Vehicles in Cancer. Nanomaterials 2017, 7, 189. [CrossRef] [PubMed]

17. Durfee, P.N.; Lin, Y.-S.; Dunphy, D.R.; Muñiz, A.J.; Butler, K.S.; Humphrey, K.R.; Lokke, A.J.; Agola, J.O.; Chou, S.S.; Chen, I.-M.; et al. Mesoporous Silica Nanoparticle-Supported Lipid Bilayers (Protocells) for Active Targeting and Delivery to Individual Leukemia Cells. ACS Nano 2016, 10, 8325-8345. [CrossRef]

18. Babaei, M.; Abnous, K.; Taghdisi, S.M.; Farzad, S.A.; Peivandi, M.T.; Ramezani, M.; Alibolandi, M. Synthesis of theranostic epithelial cell adhesion molecule targeted mesoporous silica nanoparticle with gold gatekeeper for hepatocellular carcinoma. Nanomedicine 2017, 12, 1261-1279. [CrossRef]

19. Zhou, S.; Wu, D.; Yin, X.; Jin, X.; Zhang, X.; Zheng, S.; Wang, C.; Liu, Y. Intracellular pH-responsive and rituximab-conjugated mesoporous silica nanoparticles for targeted drug delivery to lymphoma B cells. J. Exp. Clin. Cancer Res. 2017, 36, 24. [CrossRef] [PubMed]

20. Li, M.; Zhang, W.; Wang, B.; Gao, Y.; Song, Z.; Zheng, Q. Ligand-based targeted therapy: A novel strategy for hepatocellular carcinoma. Int. J. Nanomed. 2016, 11, 5645-5669. [CrossRef]

21. Paterni, I.; Bertini, S.; Granchi, C.; Macchia, M.; Minutolo, F. Estrogen receptor ligands: A patent review update. Expert Opin. Ther. Patents 2013, 23, 1247-1271. [CrossRef]

22. Yip, C.-H.; Rhodes, A. Estrogen and progesterone receptors in breast cancer. Future Oncol. 2014, 10, 2293-2301. [CrossRef] [PubMed]

23. Gadag, S.; Sinha, S.; Nayak, Y.; Garg, S.; Nayak, U.Y. Combination Therapy and Nanoparticulate Systems: Smart Approaches for the Effective Treatment of Breast Cancer. Pharmaceutics 2020, 12, 524. [CrossRef] [PubMed]

24. Elledge, R.M.; Green, S.; Pugh, R.; Allred, D.C.; Clark, G.M.; Hill, J.; Ravdin, P.; Martino, S.; Osborne, C.K. Estrogen receptor (ER) and progesterone receptor (PgR), by ligand-binding assay compared with ER, PgR and pS2, by immuno-histochemistry in predicting response to tamoxifen in metastatic breast cancer: A Southwest Oncology Group Study. Int. J. Cancer 2000, 89, 111-117. [CrossRef]

25. Wiseman, H. Tamoxifen: Molecular basis of use in cancer treatment and prevention. Gen. Pharmacol. 1996, 5, 923.

26. Day, C.M.; Hickey, S.M.; Song, Y.; Plush, S.E.; Garg, S. Novel Tamoxifen Nanoformulations for Improving Breast Cancer Treatment: Old Wine in New Bottles. Molecules 2020, 25, 1182. [CrossRef]

27. Jain, A.S.; Goel, P.N.; Shah, S.M.; Dhawan, V.V.; Nikam, Y.; Gude, R.P.; Nagarsenker, M.S. Tamoxifen guided liposomes for targeting encapsulated anticancer agent to estrogen receptor positive breast cancer cells: In vitro and in vivo evaluation. Biomed. Pharmacother. 2014, 68, 429-438. [CrossRef]

28. Dreaden, E.C.; Mwakwari, S.C.; Sodji, Q.H.; Oyelere, A.K.; El-Sayed, M.A. Tamoxifen-Poly(ethylene glycol)-Thiol Gold Nanoparticle Conjugates: Enhanced Potency and Selective Delivery for Breast Cancer Treatment. Bioconjug. Chem. 2009, 20, 2247-2253. [CrossRef]

29. Paris, J.L.; Cabañas, M.V.; Manzano, M.; Vallet-Regí, M. Polymer-Grafted Mesoporous Silica Nanoparticles as UltrasoundResponsive Drug Carriers. ACS Nano 2015, 9, 11023-11033. [CrossRef]

30. Climent, E.; Biyikal, M.; Gröninger, D.; Weller, M.G.; Martínez-Máñez, R.; Rurack, K. Multiplexed Detection of Analytes on Single Test Strips with Antibody-Gated Indicator-Releasing Mesoporous Nanoparticles. Angew. Chem. Int. Ed. 2020, 59, 2-10. [CrossRef]

31. Vivo-Llorca, G.; Candela-Noguera, V.; Alfonso, M.; García-Fernández, A.; Orzáez, M.; Sancenón, F.; Martínez-Máñez, R. MUC1 Aptamer-Capped Mesoporous Silica Nanoparticles for Navitoclax Resistance Overcoming in Triple-Negative Breast Cancer. Chem.-A Eur. J. 2020, 26, 16318-16327. [CrossRef]

32. Poyatos-Racionero, E.; Gonzalez-Alvarez, I.; González-Álvarez, M.; Martínez-Máñez, R.; Marcos, M.D.; Bernardos, A.; Aznar, E. Surfactant-Triggered Molecular Gate Tested on Different Mesoporous Silica Supports for Gastrointestinal Controlled Delivery. Nanomaterials 2020, 10, 1290. [CrossRef] [PubMed] 
33. Añón, E.; Costero, A.M.; Amorós, P.; El Haskouri, J.; Martínez-Mánez, R.; Parra, M.; Gil, S.; Gaviña, P.; Terencio, M.C.; Alfonso, M. Peptide-Capped Mesoporous Nanoparticles: Toward a more Efficient Internalization of Alendronat. ChemistrySelect 2020, 5, 3618. [CrossRef]

34. Midoux, P.; Pichon, C.; Yaouanc, J.-J.; Jaffrès, P.-A. Chemical vectors for gene delivery: A current review on polymers, peptides and lipids containing histidine or imidazole as nucleic acids carriers. Br. J. Pharmacol. 2009, 157, 166-178. [CrossRef] [PubMed]

35. Zeng, Y.F.; Tseng, S.J.; Kempson, I.M.; Peng, S.F.; Wu, W.T.; Liu, J.R. Controlled delivery of recombinant adeno-associated virus serotype 2 using pH-sensitive poly(ethylene glycol)-poly-L-histidine hydrogels. Biomaterials 2012, 33, 9239-9245. [CrossRef]

36. Mu, S.; Liu, Y.; Wang, T.; Zhang, J.; Jiang, D.; Yu, X.; Zhang, N. Unsaturated nitrogen-rich polymer poly(l-histidine) gated reversibly switchable mesoporous silica nanoparticles using "graft to" strategy for drug controlled release. Acta Biomater. 2017, 63, 150-162. [CrossRef]

37. Huang, H.; Yuan, S.; Ma, Z.; Ji, P.; Ma, X.; Wu, Z.; Qi, X. Genetic recombination of poly(l-lysine) functionalized apoferritin nanocages that resemble viral capsid nanometer-sized platforms for gene therapy. Biomater. Sci. 2020, 8, 1759-1770. [CrossRef]

38. Al-Lohedan, H.; Bunton, C.A. Ion binding and micellar effects upon reactions of carboxylic anhydrides and carbonate esters. J. Org. Chem. 1982, 47, 1160-1166. [CrossRef]

39. Miricioiu, M.G.; Iacob, C.; Nechifor, G.; Niculescu, V.-C. High Selective Mixed Membranes Based on Mesoporous MCM-41 and MCM-41-NH2 Particles in a Polysulfone Matrix. Front. Chem. 2019, 7, 332. [CrossRef]

40. Zhou, X.; Feng, W.; Qiu, K.; Chen, L.; Wang, W.; Nie, W.; Mo, X.; He, C. BMP-2 Derived Peptide and Dexamethasone Incorporated Mesoporous Silica Nanoparticles for Enhanced Osteogenic Differentiation of Bone Mesenchymal Stem Cells. ACS Appl. Mater. Interfaces 2015, 7, 15777-15789. [CrossRef]

41. Zhu, L.; Zhou, L.; Huang, N.; Cui, W.; Liu, Z.; Xiao, K.; Zhou, Z. Efficient Preparation of Enantiopure D-Phenylalanine through Asymmetric Resolution Using Immobilized Phenylalanine Ammonia-Lyase from Rhodotorula glutinis JN-1 in a Recirculating Packed-Bed Reactor. PLoS ONE 2014, 9, e108586. [CrossRef]

42. Zhai, Q.; Zhou, C.; Zhao, S.; Peng, C.; Han, Y. Kinetic Study of Alkoxysilane Hydrolysis under Acidic Conditions by Fourier Transform Near Infrared Spectroscopy Combined with Partial Least-Squares Model. Ind. Eng. Chem. Res. 2014, 53, 13598-13609. [CrossRef]

43. D'Angelo, J. FT-IR determination of aliphatic and aromatic C-H contents of fossil leaf compressions. Part 2: Applications. ALDEQ 2004, 8, 34-38.

44. Bagiyan, G.A.; Koroleva, I.K.; Soroka, N.V.; Ufimtsev, A.V. Oxidation of thiol compounds by molecular oxygen in aqueous solutions. Russ. Chem. Bull. 2003, 52, 1135-1141. [CrossRef]

45. Brewer, C.F.; Riehm, J.P. Evidence for possible nonspecific reactions between N-ethylmaleimide and proteins. Anal. Biochem. 1967, 18, 248-255. [CrossRef]

46. Fowles, J.; Banton, M.; Klapacz, J.; Shen, H. A toxicological review of the ethylene glycol series: Commonalities and differences in toxicity and modes of action. Toxicol. Lett. 2017, 278, 66-83. [CrossRef]

47. Ho, L.A.; Thomas, E.; McLaughlin, R.A.; Flematti, G.R.; Fuller, R.O. A new selective fluorescent probe based on tamoxifen. Bioorg. Med. Chem. Lett. 2016, 26, 4879-4883. [CrossRef]

48. Zhang, F.; Song, M.-R.; Yuan, G.-K.; Ye, H.-N.; Tian, Y.; Huang, M.; Xue, J.-P.; Zhang, Z.-H.; Liu, J. A Molecular Combination of Zinc(II) Phthalocyanine and Tamoxifen Derivative for Dual Targeting Photodynamic Therapy and Hormone Therapy. J. Med. Chem. 2017, 60, 6693-6703. [CrossRef]

49. Smith, B. Hydrocarbons. In Infrared Spectral Interpretation: A Systematic Approach, 1st ed.; CRC Press: Boca Raton, FL, USA, 1999; pp. 30-66.

50. Shchukarev, A.; Korolkov, D. XPS Study of group IA carbonates. Open Chem. 2004, 2, 347-362. [CrossRef]

51. Nohira, H.; Tsai, W.; Besling, W.F.A.; Young, E.; Petry, J.; Conard, T.; Vandervorst, W.; De Gendt, S.; Heyns, M.M.; Maes, J.; et al. Characterization of ALCVD-A12O3 and ZrO2 layer using X-ray photoelectron spectroscopy. J. Non-Cryst. Solids 2002, $303,83-87$. [CrossRef]

52. Wang, R.; Chu, C.; Hu, T.; Dong, Y.; Guo, C.; Sheng, X.; Lin, P.; Chung, C.; Chu, P. Surface XPS characterization of NiTi shape memory alloy after advanced oxidation processes in UV/H2O2 photocatalytic system. Appl. Surf. Sci. 2007, 253, 8507-8512. [CrossRef]

53. Green, S.M.; Grant, D.M.; Wood, J.V. XPS characterisation of surface modified Ni-Ti shape memory alloy. Mater. Sci. Eng. A 1997, 224, 21-26. [CrossRef]

54. Gottlieb, H.E.; Kotlyar, V.; Nudelman, A. NMR Chemical Shifts of Common Laboratory Solvents as Trace Impurities. J. Org. Chem. 1997, 62, 7512-7515. [CrossRef] [PubMed]

55. BeckShon, H.P.; Brooke, S.K.; Bregman, H.; Cee, V.J.; Chakka, N.; Cushing, T.D.; Epstein, O.; Fox, B.M.; Geuns-Meyer, S.; Hao, X.; et al. WO2015129926A1: Pyrazole Amide Derivative. WIPO 2015. 89. Available online: https://patents.google.com/patent/ WO2015129926A1 (accessed on 14 April 2019).

56. Xie, M.; Shi, H.; Li, Z.; Shen, H.; Ma, K.; Li, B.; Shen, S.; Jin, P.Y. A multifunctional mesoporous silica nanocomposite for targeted delivery, controlled release of doxorubicin and bioimaging. Colloids Surfaces B Biointerfaces 2013, 110, 138-147. [CrossRef] [PubMed] 